\title{
APPLICATION OF GAS HYDRATE TECHNOLOGIES FOR COAL MINE METHANE TRANSPORTATION
}

\author{
K.S. Sai ${ }^{1 *}$ \\ ${ }^{1}$ Dnipro University of Technology, Dnipro, Ukraine \\ *Corresponding author: e-mail: kateryna.sai@gmail.com
}

\section{ЗАСТОСУВАННЯ ГАЗОГІДРАТНИХ ТЕХНОЛОГІЙ ДЛЯ ТРАНСПОРТУВАННЯ МЕТАНУ ВУГІЛЬНИХ ШАХТ}

\author{
К.С. Сай ${ }^{1 *}$ \\ ${ }^{1}$ Національний технічний університет «Дніпровська політехніка», м. Дніпро, \\ Україна \\ *Відповідальний автор: e-mail: kateryna.sai@gmail.com
}

\begin{abstract}
Purpose. Improving the efficiency of application of gas hydrate technologies for converting coal mine methane into a solid crystalline state with its subsequent transportation to consumers by intensifying the hydrate formation process.

Methods. Experimental studies were carried out in the laboratory of innovative technologies of the Dnipro University of Technology (Dnipro, Ukraine). The thermobaric parameters of the hydrate formation process varied to produce of gas hydrate samples from mine methane by artificial means. Physical modeling and field experiments were carried out in an ILKA KTK-3000 climate chamber, as well as on an NPO-5 unit, which made it possible to simulate specified thermobaric parameters (temperature, pressure). The least squares method was used to determine the linear regression parameters.

Findings. Gas hydrates and their thermobaric conditions were experimentally obtained under three variants: free mixing of gas and water in a reactor, forced mixing of a water-gas mixture and mixing of a water-gas mixture in a magnetic field. The functional relationship between the initial parameters of the hydrate formation process is determined for the three variants considered. The adequacy of the constructed models was verified by calculating the determination coefficient for each model using the square of the linear correlation coefficient. It is reasonable to transportation of gas in a solid gas hydrate state due to the effect of selfpreservation, which is safer and economically feasible.

Originality. By mathematical modeling found that the determination indices for all the considered variants of the hydrate formation process are larger than the determination coefficients, which confirms the fact that the parabolic model is more adequate.
\end{abstract}


Practical implications. The optimal method for intensification of the hydrate formation process for substantiating artificially created gas hydrates from coal mine methane as an alternative energy source is justified.

Keywords: gas hydrate, methane, crystallization centers, intensification, effect of self-preservation, transportation

\section{INTRODUCTION}

Despite the rapid development of scientific and technological progress, underground coal mining in Ukraine remains difficult and due to insignificant thickness of seams, their gas-bearing content and unstable rocks [1]. Analysis of the development of coal deposits in modern conditions shows the need for new solutions to a number of problems in terms of ensuring the safety of mines, integrated development of mineral resources and environmental protection $[2,3]$. Such problems include the problem of methane utilization, which is discharged to the surface in various ways of degassing, as well as being carried by a ventilating air jet to the surface of the earth. The activity of the coal-industrial complex of Ukraine today is controlled by many regulatory acts, among which methane gas occupies a special place [4].

Modern technologies of coal mining underground cause, that the atmosphere receives a huge amount of hydrocarbon, which is, of course, a topical problem for not only the coal industry, but the whole country. Many scientific works are devoted to the issue of coal methane processing [5-7]. It should also be noted that the high prices for hydrocarbons, the depletion of traditional gas fields, the use of hydrocarbons as an argument in international relations are pushing the international community to develop alternative energy projects. About half of US natural gas production is already provided through non-traditional natural gas, and alternative energy development projects are being actively developed in Canada, the United Kingdom, Poland, Turkey and Ukraine.

Analysis of the composition of gas coming to the surface from the degassing wells of Ukraine's coal mines shows that the methane content ranges from 2 to $95 \%$. Well flow rates also vary over wide ranges [8]. In view of this, the task is to find a way of utilizing coal gas for which the chemical composition would not be a harsh condition. Today, this solution is the conversion of gas mixtures of degassing wells into a solid state, i.e. the formation of gas hydrates [9].

Gas hydrates are compounds of gas and water that are stable at low temperatures and high pressures. Gas hydrates refers to non-stoichiometric compounds, i.e. compounds of variable composition. The most common gas hydrates are methane hydrates. Gas hydrate technology for the storage and transportation of natural gas is a real future prospect, since $1 \mathrm{~m}^{3}$ of gas hydrate contains about $200 \mathrm{~m}^{3}$ of methane, which is not characterized by spontaneous combustion inherent in free or liquefied methane $[10,11]$. Obtaining gas hydrates from the methane-air mixture of their transportation are quite relevant at the present time and economically feasible in the development of coal deposits [12]. The integrated approach will allow to integrate coal and methane technology into a single system, increase the profitability of coal mines, safety of work and ensure the energy independence of our country $[13,14]$. 


\section{METHOD OF RESEARCH}

In developing a method for producing gas hydrates, one of the main tasks is to accelerate the hydration process. To date, in the experimental study of the kinetics of gas hydrate formation, there are two fundamentally different directions: the first - when the studies are conducted in the absence of forced mixing, i.e., the supply of hydrate-forming components occurs as a result of diffusion, and heat dissipation in heat and law; and the second direction (dynamic mode), when the effect of diffusion and thermal conductivity is removed by mixing the substance.

In the laboratory of innovative technologies of Dnipro University of Technology (Dnipro, Ukraine), thermobaric parameters of the hydration formation process were created during the experimental researches and samples of gas hydrates were obtained by artificial means. Experimental research methodology is based on physical modeling and field experiments in the KTK-3000 climate chamber [15]. The basis of the technique is the use of the experimental unit of NPO-5, which allows to simulate the given thermobaric parameters of the process of obtaining gas hydrates in a wide range of temperatures and pressures [16].

Laboratory research were aimed to creating samples of pure gas hydrate. In general, the method of laboratory research included the preparation of samples for physical modeling, conducting a series of experiments and processing of the obtained experimental data.

\section{METHODS OF INTENSIFICATION OF THE GAS HYDRATE FOR- MATION}

To develop a process of continuous production of gas hydrates, it is necessary to understand the kinetics of gas hydrate formation. Most known research of gas hydrates are mainly focused on studying the mechanism of their formation and dissociation [17-19]. At the same time, their results showed that these processes occur rather slowly. Formation of gas hydrates under laboratory conditions usually takes from several hours to several days.

Devices for the formation of artificial gas hydrates differ in the ways of creating interphase gas-water contact:

- spraying water into the gas phase;

- introducing gas into the liquid phase by foaming the substances;

- combined method of introducing of reagents.

One of the main direct of physical-chemical research of gas hydrates is the study of the kinetics of hydrate formation, which is especially relevant when modeling the process of obtaining of gas hydrates in laboratory and industrial conditions [20].

To intensification of gas hydrates formation process it is possible to use the following methods [21, 22]:

- application of surface-active substance (SAS);

- impact of the shock wave on the water-gas mixture;

- application of electromagnetic static field;

- intense mixing of water saturated of gas dissolved in it. 
It is established that the use of SAS influences on the period of crystallization centers nucleation, the size and concentration of hydrated particles at the stages of their nucleation and growth. It is established that at the nucleation stage SAS increase the number of crystallization centers, and at the hydrate growth stage inhibit the processes of hydrate particle aggregation [23]. As an aqueous hydrationforming medium, it is possible to use an aqueous solution of low-concentration SAS at a pressure and temperature above the equilibrium required for gas hydrate formation [24]. Cationic, anionic, or nonionic surfactants, such as polyoxyethylene ethers, sorbitans, long-chain alcohols, sulphates, diols, fatty acids, alkylated ammonium compounds, sulphonyls, sulfonates, can be used as accelerators of the gas hydrate formation process. Preferably, the SAS is a quaternary ammonium compound containing four alkyl groups, of which at least one has from 1 to 6 carbon atoms.

To increase the kinetics of gas hydrate formation, it is also possible to create of shock waves of pressure in a gas-liquid medium. Such waves can be generated by electromagnetic pulse emitters or pneumatic shocks, or other devices, and can reach values in hundreds of atmospheres. The propagation of a shock wave of sufficient length over the gas-liquid medium, due to the weak attenuation, leads to the following physical phenomenon: the gas phase is crushed into small gas bubbles. Therefore, the interphase surface increases. Moreover, increasing the intensity of the shock wave leads to the fragmentation of the gas phase into smaller inclusions. The relative kinetics of gas inclusions in a fluid in a shock wave pressure significantly exceeds the relative kinetics of the gas phase in the absence of a shock wave. As the wave amplitude increases, the relative kinetics of the gas phase in the liquid increases.

The electromagnetic static field also significantly affects the kinetics of gas hydrate growth. Research of the influence of electromagnetic fields on gas hydrate formation processes have shown that denser and more stable crystalline hydrates are formed under these conditions. In addition, it was found that under the influence of magnetic fields, the accumulation of gas hydrates is significantly accelerated.

\section{RESULTS OF RESEARCH}

Experimental studies of the gas hydrate formation process were performed in three variants:

variant 1 - free mixing of gas and water in a reactor;

variant 2 - forced mixing of water-gas mixture;

variant 3 - mixing of a water-gas mixture in a magnetic field.

When conducting the experiment in the reactor of gas hydrate formation was set to a constant pressure of $7 \mathrm{MPa}$, the experiment was carried out in a temperature range from +0.5 to $+7.5^{\circ} \mathrm{C}$, technologically mixing in the reactor gas and water. To create a magnetic field, 4 magnets were placed inside the reactor.

In the first variant, the first signs of gas hydrate formation were detected at $+0.5^{\circ} \mathrm{C}$ after 6.1 hours; in the second, at the same thermobaric parameters, - after 4 hours; and for the third - after 2 hours (Fig. 1). 


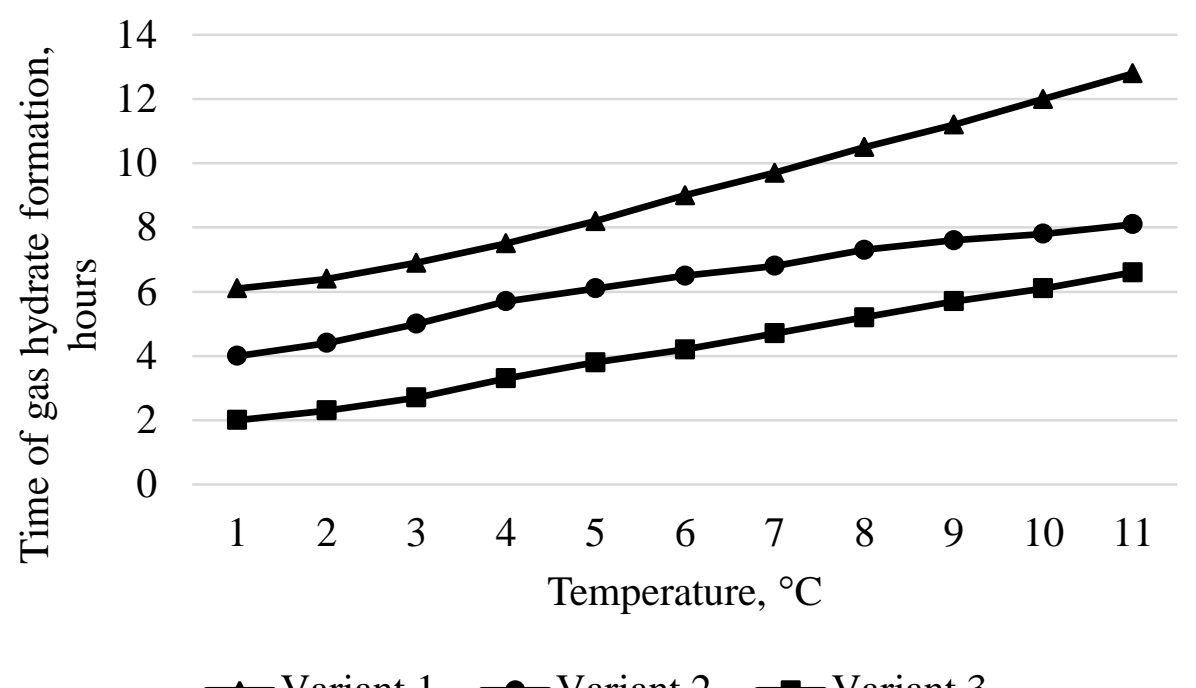

$\rightarrow$ Variant $1 \rightarrow$ Variant $2 \rightarrow$ Variant 3

Figure 1. Formation periods of gas hydrates in three variants: variant 1 -free mixing of gas and water in a reactor; variant 2 -forced mixing of water-gas mixture; variant 3 - mixing of a water-gas mixture in a magnetic field

To analyze the data obtained in the experimental studies, the functional dependence between the original parameters for all variants was determined. The adequacy of the constructed models was verified by calculating the determination coefficient for each model.

The least squares method was used to determine linear regression parameters. Let between the data $\left(x_{i}, y_{i}\right)$ there is a linear relationship. General view of linear dependence $-y=a x+b$, where $a$ and $b$ are unknown. Model parameters were calculated by the formulas:

$$
\begin{gathered}
a=\frac{n \sum_{i=1}^{n} x_{i} y_{i}-\sum_{i=1}^{n} x_{i} \cdot \sum_{i=1}^{n} y_{i}}{n \sum_{i=1}^{n} x_{i}^{2}-\left(\sum_{i=1}^{n} x_{i}\right)^{2}} ; \\
b=\frac{\sum_{i=1}^{n} y_{i} \cdot \sum_{i=1}^{n} x_{i}^{2}-\sum_{i=1}^{n} x_{i} y_{i} \cdot \sum_{i=1}^{n} x_{i}}{n \sum_{i=1}^{n} x_{i}^{2}-\left(\sum_{i=1}^{n} x_{i}\right)^{2}} .
\end{gathered}
$$

A modified least squares method was used to determine the parabolic regression parameters.

Let between the data $\left(x_{i}, y_{i}\right)$ there is a parabolic dependence. General view of parabolic dependence $-y=a x^{2}+b x+c$, where $a, b$ and $c$ are unknown. The model parameters are calculated from the following system of equations: 


$$
\left\{\begin{array}{l}
a \sum_{i=1}^{n} x_{i}^{4}+b \sum_{i=1}^{n} x_{i}^{3}+c \sum_{i=1}^{n} x_{i}^{2}=\sum_{i=1}^{n} x_{i}^{2} y_{i} \\
a \sum_{i=1}^{n} x_{i}^{3}+b \sum_{i=1}^{n} x_{i}^{2}+c \sum_{i=1}^{n} x_{i}=\sum_{i=1}^{n} x_{i} y_{i} \\
a \sum_{i=1}^{n} x_{i}^{2}+b \sum_{i=1}^{n} x_{i}+n c=\sum_{i=1}^{n} y_{i}
\end{array}\right.
$$

The adequacy of the constructed models was verified by calculating the determination coefficient for each model. To evaluate the quality of the selection of the linear function, the square of the linear correlation coefficient was calculated $r_{x y}^{2}$, called the coefficient of determination. The coefficient of determination characterizes the proportion of variance of the productive trait $y$, which is explained by regression in the total variance of the productive trait:

$$
r_{x y}^{2}=1-\frac{\sigma_{f i n}^{2}}{\sigma_{y}^{2}},
$$

where:

$$
\begin{gathered}
E S S=\sigma_{\text {fin }}^{2}=\frac{1}{n} \sum\left(y-\hat{y}_{x}\right)^{2} ; \\
T S S=\sigma_{y}^{2}=\frac{1}{n} \sum(y-\bar{y})^{2}=\bar{y}^{2}-\bar{y}^{2} .
\end{gathered}
$$

The generalized results of the calculated parameters for the linear model are shown in Figure 2, with the determination coefficients for each variant.

The quality of a nonlinear regression model is determined by a nonlinear correlation index called the correlation index for nonlinear forms of communication. It is calculated using the dispersion decomposition theorem. The determination index for the nonlinear coupling characteristics is similar to the normal coefficient of determination.

If the nonlinear regression equation using factor substitutions can be reduced to a paired linear regression equation, then all the hypothesis testing methods for the paired linear dependence will apply to this equation:

$$
R_{x y}^{2}=1-\frac{E S S}{T S S}=1-\frac{\sigma_{o c m}^{2}}{\sigma_{y}^{2}}=1-\frac{\sum_{i=1}^{n}\left(y_{i}-y_{x}\right)^{2}}{\sum_{i=1}^{n}\left(y_{i}-\bar{y}\right)^{2}} .
$$




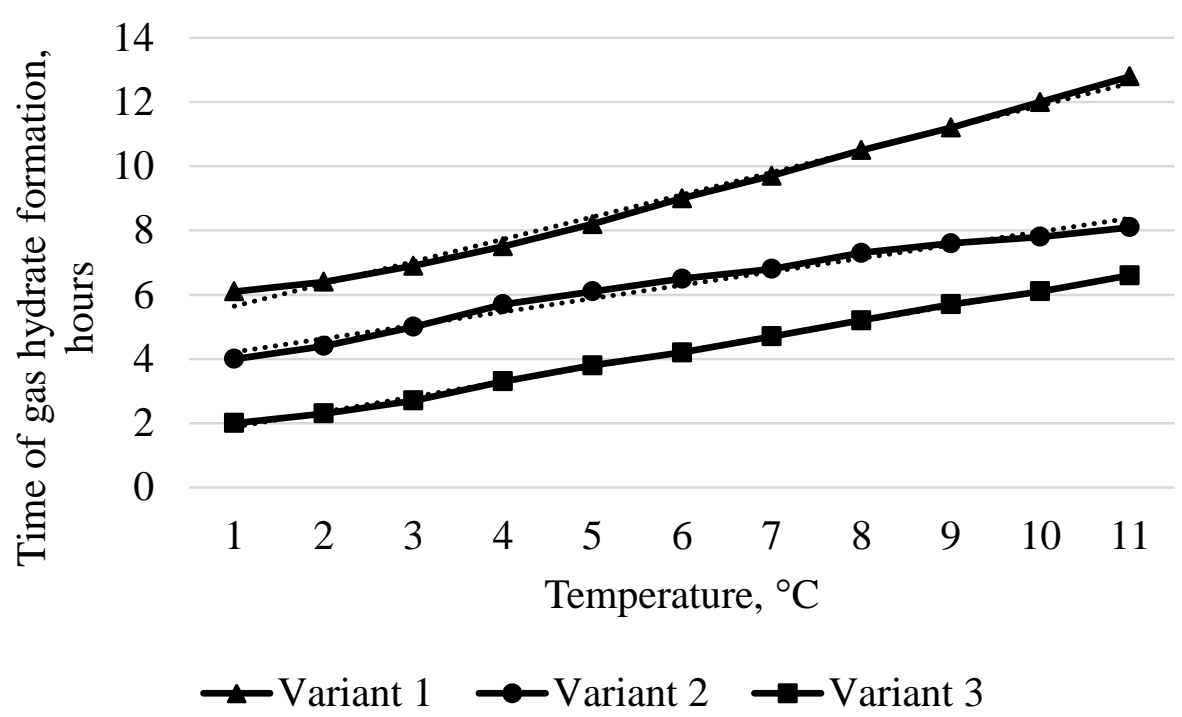

Figure 2. Linear regression models and equations with coefficients of determination for each of the three variants

Generalized results of the calculated parameters for the parabolic model are shown in Figure 3 with the determination indices for each variant.

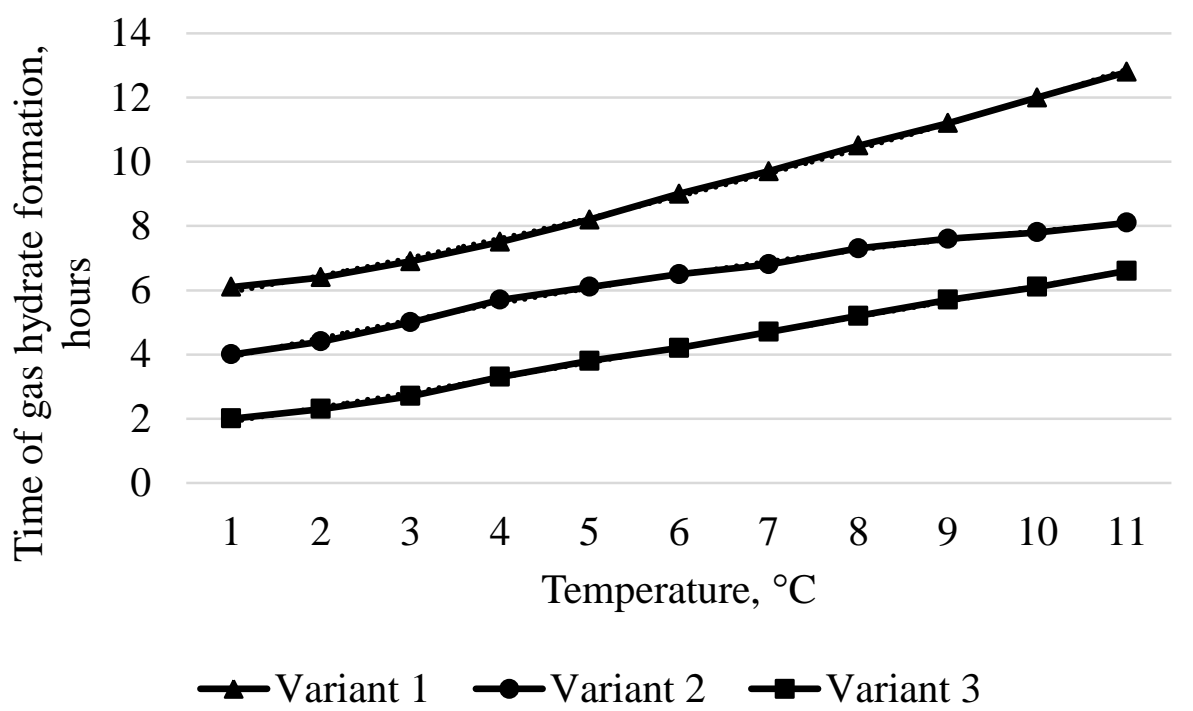

Figure 3. Parabolic regression models and equations with determination indices for each of the three variants

To perform the adequacy analysis and module selection, the results obtained were summarized in a common table (Table 1).

Therefore, since the determination indices for all variants are greater than the coefficients of determination, the parabolic model is more adequate. 
Table 1. Determination coefficients (indices) for the constructed models

\begin{tabular}{|l|c|c|}
\hline & Linear model & Parabolic model \\
\hline Variant 1 & 0.9723 & 0.9984 \\
\hline Variant 2 & 0.9869 & 0.9972 \\
\hline Variant 3 & 0.9984 & 0.9986 \\
\hline
\end{tabular}

We finally accept the equation of dependence between the parameters of the formation time of gas hydrates $(T)$ from the temperature $(t)$ :

- for variant $1-T(t)=0.0195 t^{2}+0.4601 t+5.4624$

- for variant $2-T(t)=-0.0198 t^{2}+0.6541 t+3.2867$

- for variant $3-T(t)=0.0017 t^{2}+0.4508 t+1.4509$.

\section{SUBSTANTIATE OF METHOD OF COAL MINE METHANE TRANS- PORTATION IN GAS HYDRATE STATE}

When developing a method of transportation gas, safety and cost factors must be paramount [25] Currently, two variants are being considered: in gas hydrate state and liquefied state. The second method has become more widely used, but only because the application of the self-preservation effect of gas hydrates at the industrial level has not yet been fully understood. And thanks to this effect, natural gas can be transported in a solid gas hydrate state at atmospheric pressure and negative temperatures.

Self-preservation of gas hydrates is known as a very slow hydrate decomposition when the outside pressure drops below the equilibrium value for the "gas-icegas hydrate" system at a temperature below zero degrees and, as a consequence, an icy crust is formed on the surface of the hydrate, which significantly reduces the kinetics dissociation of gas hydrate. This property of gas hydrates is critical and plays a significant role in substantiate the parameters of their transportation under atmospheric pressure and temperatures below zero degrees Celsius.

Studies have shown that only the presence of a crust on the surface of a gas hydrate is an insufficient condition. It is also necessary to take into account the role of such factors as the ratio between pressure and temperature, the microstructure of ice, the kinetics of formation of ice crystals, the composition of gas. The combination of these factors leads to the effect that the formation of a sufficiently thin crust creates a sufficient diffusion barrier for the released gas molecules. It is likely that the released gas molecules dissolve in the boundary layer between the ice and the gas hydrate, maintaining the necessary chemical activity for the stability of the latter, thus, the icy crust does not require high pressure. Therefore, selfpreservation should be considered as a complex phenomenon in which part of the gas hydrate, which is exposed to external factors, is spent in order to form a protective ice crust.

Table 2 provides a comparison of two methods of gas transportation. 
Физико-технические проблемы горного производства 2020, вып. 22

Table 2. Comparison of properties of gas hydrates and liquefied gas

\begin{tabular}{|l|c|c|}
\hline \multicolumn{1}{|c|}{ Characteristic } & Gas hydrates & Liquefied natural gas \\
\hline State & solid & liquid \\
\hline Gas content in $1 \mathrm{~m}^{3}, \mathrm{~m}^{3}$ & up to 200 & up to 600 \\
\hline Temperature, ${ }^{\circ} \mathrm{C}$ & $-20^{\circ} \mathrm{C}$ & $-162^{\circ} \mathrm{C}$ \\
\hline Specific gravity, $\mathrm{kg} / \mathrm{m}^{3}$ & $850.00-950.00$ & $420.00-470.00$ \\
\hline
\end{tabular}

From Table 2 it is obvious that gas hydrates can be transported at a higher temperature than gas in the liquefied state. This allows us to speak about the costeffectiveness of this mode of transportation. There are also advantages such as capital and operating costs, energy consumption, greenhouse gas emissions during formation and transportation, and, most importantly, safety in gas transportation, since the possibility of a sudden explosion reduces to zero.

It should be noted that special gas-tight containers are required to transport gas in the form of gas hydrates. During the transport of hydrates, the pressure and temperature inside the tank must be controlled to prevent the ice crust from melting on the surface of the hydrates. As already mentioned, the transportation of hydrates can be carried out even at atmospheric pressure and temperature below zero degrees Celsius. Therefore, it is necessary to apply active cooling of the space in which gas hydrates are located in order to maintain the required transportation temperature.

\section{CONCLUSIONS}

1. The existing methods of intensification of the process of gas hydrate formation are analyzed, the features of devices (units) for obtaining artificial gas hydrates are revealed.

2. Experimental researches on creation of gas hydrates have been carried out and thermobaric parameters of the gas hydrate formation process have been established using various methods of process intensification.

3. The functional dependence between the initial parameters of the gas hydrate formation process for 3 considered variants is determined. The least squares method was used to determine linear regression parameters. A modified least squares method was used to determine the parameters of the parabolic regression that was accepted in the calculations.

4. The adequacy of the constructed models is verified by calculating the coefficient of determination for each model using the square of the linear coefficient of correlation. As a result, the determination indices for all variants have more determination coefficients, which confirms the fact that the parabolic model is more adequate.

5. Comparison of the parameters of gas transportation methods. Emphasis is placed on the technology of gas transportation in the solid gas hydrate state due to the self-preservation effect, which is more secure and economically feasible when comparing the thermobaric parameters of gas mixture transportation. 


\section{ACKNOWLEDGEMENTS}

The presented results were obtained in the framework of the complex implementation of research papers GP-500 «Synthesis, optimization and parameterisation of innovation technologies for the development of gas-coal fields resources» (State registration No. 0119U000248).

\section{REFERENCES}

1. Khorolskyi, A., Hrinov, V., Mamaikin, O., \& Demchenko, Y. (2019). Models and methods to make decisions while mining production scheduling. Mining of Mineral Deposits, 13(4), 53-62. https://doi.org/10.33271/mining13.04.053

2. Petlovanyi, M., Lozynskyi, V., Saik, P., \& Sai, K. (2019). Predicting the producing well stability in the place of its curving at the underground coal seams gasification. E3S Web of Conferences, (123), 01019. https://doi.org/10.1051/e3sconf/201912301019

3. Khorolskyi, A., Hrinov, V., \& Kaliushenko, O. (2019). Network models for searching for optimal economic and environmental strategies for field development. Procedia Environmental Science, Engineering and Management, 6(3), 463-471.

4. 95/05871 Coal-bed methane in Ukraine: Facta and prospects. (1995). Fuel and Energy Abstracts, 36(6), 418. https://doi.org/10.1016/0140-6701(95)97514-k

5. Alsaab, D., Elie, M., Izart, A., Sachsenhofer, R.F., Privalov, V.A., Suarez-Ruiz, I., \& Panova, E.A. (2009). Distribution of thermogenic methane in Carboniferous coal seams of the Donets Basin (Ukraine): "Applications to exploitation of methane and forecast of mining hazards." International Journal of Coal Geology, 78(1), 27-37. https://doi.org/10.1016/j.coal.2008.09.004

6. Boger, C., Marshall, J.S., \& Pilcher, R.C. (2014). Worldwide coal mine methane and coalbed methane activities. Coal Bed Methane, 351-407. https://doi.org/10.1016/b978-0-12-800880-5.00018-8

7. Ganushevych, K., Sai, K., \& Korotkova, A. (2014). Creation of gas hydrates from mine methane. Progressive Technologies of Coal, Coalbed Methane, and Ores Mining, 505-509. https://doi.org/10.1201/b17547-85

8. Cai, J., Xu, C., Xia, Z., Chen, Z., \& Li, X. (2017). Hydrate-based methane recovery from coal mine methane gas in scale-up equipment with bubbling. Energy Procedia, (105), 4983-4989. https://doi:10.1016/j.egypro.2017.03.996

9. Diedich, I., \& Nazimko, V. (2014). Assessment of goaf degassing wells shear due to their longwall undermining. Progressive Technologies of Coal, Coalbed Methane, and Ores Mining, 137-140. https://doi:10.1201/b17547-25

10. Carroll, J. (2014). Natural gas hydrates: a guide for engineers. Oxford, United Kingdom: Elsevier, 340 p.

11. Makogon, Y.F. (1997). Hydrates of hydrocarbons. Tulsa, Oklahoma, United States: Pennwell Books, 482 p.

12. Sai, K., Malanchuk, Z., Petlovanyi, M., Saik, P., \& Lozynskyi, V. (2019). Research of thermodynamic conditions for gas hydrates formation from methane in the coal mines. Solid State Phenomena, (291), 155-172. https://doi.org/10.4028/ www.scientific.net/ssp.291.155

13. Hrinov, V.H., Khorolskyi, A.O., \& Kaliushchenko, O.P. (2019). Elaboration of environmental scenarios for the effective development of valuable mineral deposits. Mineral Resources of Ukraine, (2), 46-50. https://doi.org/10.31996/mru.2019.2.46-50

14. Petlovanyi, M., Sai, K., \& Prokopenko, K. (2019). Prospects of utilization mining methane on the basis of gas hydrate technologies. Topical Issues of the Development of 
Modern Science: Abstracts of III International Scientific and Practical Conference. Sofia, Bulgaria: Publishing House "ACCENT", 396-402.

15. Bondarenko, V., Svietkina, O., \& Sai, K. (2018). Effect of mechanoactivated chemical additives on the process of gas hydrate formation. Eastern-European Journal of Enterprise Technologies, 1(6(91)), 17-26. https://doi.org/10.15587/17294061.2018.123885

16. Ovchynnikov, M., Ganushevych, K., \& Sai, K. (2013). Methodology of gas hydrates formation from gaseous mixtures of various compositions. Annual ScientificTechnical Collection - Mining of Mineral Deposits 2013, 203-206. https://doi.org/10.1201/b16354-36

17. Kobayashi, I., Ito, Y., \& Mori, Y. H. (2001). Microscopic observations of clathrate-hydrate films formed at liquid/liquid interfaces. I. Morphology of hydrate films. Chemical Engineering Science, 56(14), 4331-4338. https://doi.org/10.1016/s00092509(00)00544-3

18. Servio, P., \& Englezos, P. (2003). Morphology of methane and carbon dioxide hydrates formed from water droplets. AIChE Journal, 49(1), 269-276. https://doi.org/10.1002/aic.690490125

19. Sundramoorthy, J.D., Hammonds, P., Lal, B., \& Phillips, G. (2016). Gas hydrate gas hydrate equilibrium measurement and observation of gas hydrate dissociation with/without a KHI. Procedia Engineering, (148), 870-877. https://doi.org/ 10.1016/j.proeng.2016.06.476

20. Sai, K., Petlovanyi, M., \& Prokopenko, K. (2019). Kinetic features of the dissociation process of gas hydrate deposits. XV International Scientific and Practical Conference «International Trends in Science and Technology». Warsaw, Poland: RS Global S. z O.O., 10-16.

21. Abbasian Rad, S., Rostami Khodaverdiloo, K., Karamoddin, M., Varaminian, F., \& Peyvandi, K. (2015). Kinetic study of amino acids inhibition potential of Glycine and 1 -leucine on the ethane hydrate formation. Journal of Natural Gas Science and Engineering, (26), 819-826. https://doi.org/10.1016/j.jngse.2015.06.053

22. Sa, J.-H., Kwak, G.-H., Han, K., Ahn, D., Cho, S. J., Lee, J. D., \& Lee, K.-H. (2016). Inhibition of methane and natural gas hydrate formation by altering the structure of water with amino acids. Scientific Reports, 6(1). https://doi.org/10.1038/srep31582

23. Farhang, F. (2014). Kinetics of the formation of $\mathrm{CO}_{2}$ hydrates in the presence of sodium halides and hydrophobic fumed silica nanoparticles: $\mathrm{PhD}$ Thesis. Queensland: The University of Queensland, 177. https://doi.org/10.14264/uql.2014.385

24. Kumar, A., Bhattacharjee, G., Kulkarni, B.D., \& Kumar, R. (2015). Role of surfactants in promoting gas hydrate formation. Industrial \& Engineering Chemistry Research, 54(49), 12217-12232. https://doi.org/10.1021/acs.iecr.5b03476

25. Hanushevych, K., \& Srivastava, V. (2017). Coalbed methane: places of origin, perspectives of extraction, alternative methods of transportation with the use of gas hydrate and nanotechnologies. Mining of Mineral Deposits, 11(3), 23-34. https://doi.org/10.15407/mining11.03.023

\section{СПИСОК ЛІТЕРАТУРИ}

1. Khorolskyi, A., Hrinov, V., Mamaikin, O., \& Demchenko, Y. (2019). Models and methods to make decisions while mining production scheduling. Mining of Mineral Deposits, 13(4), 53-62. https://doi.org/10.33271/mining13.04.053

2. Petlovanyi, M., Lozynskyi, V., Saik, P., \& Sai, K. (2019). Predicting the producing well stability in the place of its curving at the underground coal seams gasification. E3S Web of Conferences, (123), 01019. https://doi.org/10.1051/e3sconf/201912301019 
3. Khorolskyi, A., Hrinov, V., \& Kaliushenko, O. (2019). Network models for searching for optimal economic and environmental strategies for field development. Procedia Environmental Science, Engineering and Management, 6(3), 463-471.

4. 95/05871 Coal-bed methane in Ukraine: Facta and prospects. (1995). Fuel and Energy Abstracts, 36(6), 418. https://doi.org/10.1016/0140-6701(95)97514-k

5. Alsaab, D., Elie, M., Izart, A., Sachsenhofer, R.F., Privalov, V.A., Suarez-Ruiz, I., \& Panova, E.A. (2009). Distribution of thermogenic methane in Carboniferous coal seams of the Donets Basin (Ukraine): "Applications to exploitation of methane and forecast of mining hazards." International Journal of Coal Geology, 78(1), 27-37. https://doi.org/10.1016/j.coal.2008.09.004

6. Boger, C., Marshall, J.S., \& Pilcher, R.C. (2014). Worldwide coal mine methane and coalbed methane activities. Coal Bed Methane, 351-407. https://doi.org/10.1016/b978-0-12-800880-5.00018-8

7. Ganushevych, K., Sai, K., \& Korotkova, A. (2014). Creation of gas hydrates from mine methane. Progressive Technologies of Coal, Coalbed Methane, and Ores Mining, 505-509. https://doi.org/10.1201/b17547-85

8. Cai, J., Xu, C., Xia, Z., Chen, Z., \& Li, X. (2017). Hydrate-based methane recovery from coal mine methane gas in scale-up equipment with bubbling. Energy Procedia, (105), 4983-4989. https://doi:10.1016/j.egypro.2017.03.996

9. Diedich, I., \& Nazimko, V. (2014). Assessment of goaf degassing wells shear due to their longwall undermining. Progressive Technologies of Coal, Coalbed Methane, and Ores Mining, 137-140. https://doi:10.1201/b17547-25

10. Carroll, J. (2014). Natural gas hydrates: a guide for engineers. Oxford, United Kingdom: Elsevier, 340 p.

11. Makogon, Y.F. (1997). Hydrates of hydrocarbons. Tulsa, Oklahoma, United States: Pennwell Books, 482 p.

12. Sai, K., Malanchuk, Z., Petlovanyi, M., Saik, P., \& Lozynskyi, V. (2019). Research of thermodynamic conditions for gas hydrates formation from methane in the coal mines. Solid State Phenomena, (291), 155-172. https://doi.org/10.4028/ www.scientific.net/ssp.291.155

13. Hrinov, V.H., Khorolskyi, A.O., \& Kaliushchenko, O.P. (2019). Elaboration of environmental scenarios for the effective development of valuable mineral deposits. Mineral Resources of Ukraine, (2), 46-50. https://doi.org/10.31996/mru.2019.2.46-50

14. Petlovanyi, M., Sai, K., \& Prokopenko, K. (2019). Prospects of utilization mining methane on the basis of gas hydrate technologies. Topical Issues of the Development of Modern Science: Abstracts of III International Scientific and Practical Conference. Sofia, Bulgaria: Publishing House "ACCENT", 396-402.

15. Bondarenko, V., Svietkina, O., \& Sai, K. (2018). Effect of mechanoactivated chemical additives on the process of gas hydrate formation. Eastern-European Journal of Enterprise Technologies, 1(6(91)), 17-26. https://doi.org/10.15587/17294061.2018.123885

16. Ovchynnikov, M., Ganushevych, K., \& Sai, K. (2013). Methodology of gas hydrates formation from gaseous mixtures of various compositions. Annual ScientificTechnical Collection - Mining of Mineral Deposits 2013, 203-206. https://doi.org/10.1201/b16354-36

17. Kobayashi, I., Ito, Y., \& Mori, Y. H. (2001). Microscopic observations of clathrate-hydrate films formed at liquid/liquid interfaces. I. Morphology of hydrate films. Chemical Engineering Science, 56(14), 4331-4338. https://doi.org/10.1016/s00092509(00)00544-3 
18. Servio, P., \& Englezos, P. (2003). Morphology of methane and carbon dioxide hydrates formed from water droplets. AIChE Journal, 49(1), 269-276. https://doi.org/10.1002/aic.690490125

19. Sundramoorthy, J.D., Hammonds, P., Lal, B., \& Phillips, G. (2016). Gas hydrate gas hydrate equilibrium measurement and observation of gas hydrate dissociation with/without a KHI. Procedia Engineering, (148), 870-877. https://doi.org/10.1016/j.proeng.2016.06.476

20. Sai, K., Petlovanyi, M., \& Prokopenko, K. (2019). Kinetic features of the dissociation process of gas hydrate deposits. XV International Scientific and Practical Conference "International Trends in Science and Technology». Warsaw, Poland: RS Global S. z O.O., 10-16.

21. Abbasian Rad, S., Rostami Khodaverdiloo, K., Karamoddin, M., Varaminian, F., \& Peyvandi, K. (2015). Kinetic study of amino acids inhibition potential of Glycine and 1 -leucine on the ethane hydrate formation. Journal of Natural Gas Science and Engineering, (26), 819-826. https://doi.org/10.1016/j.jngse.2015.06.053

22. Sa, J.-H., Kwak, G.-H., Han, K., Ahn, D., Cho, S. J., Lee, J. D., \& Lee, K.-H. (2016). Inhibition of methane and natural gas hydrate formation by altering the structure of water with amino acids. Scientific Reports, 6(1). https://doi.org/10.1038/srep31582

23. Farhang, F. (2014). Kinetics of the formation of $\mathrm{CO}_{2}$ hydrates in the presence of sodium halides and hydrophobic fumed silica nanoparticles: $\mathrm{PhD}$ Thesis. Queensland: The University of Queensland, 177. https://doi.org/10.14264/uql.2014.385

24. Kumar, A., Bhattacharjee, G., Kulkarni, B.D., \& Kumar, R. (2015). Role of surfactants in promoting gas hydrate formation. Industrial \& Engineering Chemistry Research, 54(49), 12217-12232. https://doi.org/10.1021/acs.iecr.5b03476

25. Hanushevych, K., \& Srivastava, V. (2017). Coalbed methane: places of origin, perspectives of extraction, alternative methods of transportation with the use of gas hydrate and nanotechnologies. Mining of Mineral Deposits, 11(3), 23-34. https://doi.org/10.15407/mining11.03.023

\section{ABSTRACT (IN UKRAINIAN)}

Мета. Підвищення ефективності застосування газогідратних технологій для переведення шахтного метану у твердий кристалічний стан з наступним його транспортуванням до кінцевих споживачів шляхом інтенсифікації процесу гідратоутворення.

Методи. Експериментальні дослідження виконувались у лабораторії інноваційних технологій НТУ «Дніпровська політехніка» (м. Дніпро). Варіювались термобаричні параметри процесу гідратоутворення з отриманням зразків газових гідратів з шахтного метану штучним шляхом. Проведено фізичне моделювання та натурні експериментах у кліматермокамері ILKA KTК-3000, а також на установці НПО-5, що дозволяє моделювати задані термобаричні параметри (температура, тиск). Для визначення параметрів лінійної регресії було використано метод найменших квадратів.

Результати. Експериментально отримані газогідрати та їх термобаричні умови при трьох варіантах - вільному перемішуванні у реакторі газу та води, примусовому перемішування водогазової суміші й перемішуванні водогазової суміші у магнітному полі. Визначено функціональну залежність між вихідними параметрами процесу гідратоутворення для трьох розглянутих варіантів. Виконано перевірку адекватності побудованих моделей за допо- 
могою розрахунку коефіцієнта детермінації за кожною моделлю за допомогою квадрата лінійного коефіцієнта кореляції. Обгрунтовано перевезення газу у твердому газогідратному стані за рахунок ефекту самоконсервації, який $є$ більш безпечним та економічно доцільним.

Наукова новизна. Математичним моделюванням встановлено, що індекси детермінації для всіх розглянутих варіантів процесу гідратоутворення є більшими, ніж коефіцієнти детермінації, що підтверджує той факт, що параболічна модель $є$ більш адекватною.

Практична значимість. Обгрунтовано оптимальний спосіб інтенсифікації процесу гідратоутворення для отримання штучно створених газових гідратів 3 метану вугільних шахт як альтернативного енергоносія.

Ключові слова: газогідрат, метан, центри кристалізації, інтенсифікація, ефект самоконсервації, транспортування

\section{ABSTRACT (IN RUSSIAN)}

Цель. Повышение эффективности применения газогидратных технологий для перевода шахтного метана в твердое кристаллическое состояние с последующим его транспортированием к конечным потребителям путем интенсификации процесса гидратообразования.

Методы. Экспериментальные исследования выполнялись в лаборатории инновационных технологий НТУ «Днепровская политехника» (г. Днепр). Варьировались термобарические параметры процесса гидратообразования с получением образцов газовых гидратов из шахтного метана искусственным путем. Проведено физическое моделирование и натурные экспериментах в климатермокамере ILKA КТК-3000, а также на установке НПО-5, позволяющей моделировать заданные термобарические параметры (температура, давление). Для определения параметров линейной регрессии был использован метод наименьших квадратов.

Результаты. Экспериментально получены газогидраты и их термобарические условиях при трех вариантах - свободном перемешивании в реакторе газа и воды, принудительном перемешивания водогазовой смеси и перемешивании водогазовой смеси в магнитном поле. Определена функциональная зависимость между исходными параметрами процесса гидратообразования для трех рассмотренных вариантов. Выполнена проверка адекватности построенных моделей с помощью расчета коэффициента детерминации по каждой модели с помощью квадрата линейного коэффициента корреляции. Обоснованно транспортирование газа в твердом газогидратном состоянии за счет эффекта самоконсервации, который является более безопасным и экономически целесообразным.

Научная новизна. Математическим моделированием установлено, что индексы детерминации для всех рассмотренных вариантов процесса гидратообразования являются большими, чем коэффициенты детерминации, что подтверждает тот факт, что параболическая модель является более адекватной.

Практическая значимость. Обоснованно оптимальный способ интенсификации процесса гидратообразования для получения искусственно созданных 
газовых гидратов из метана угольных шахт в качестве альтернативного энергоносителя.

Ключевые слова: газогидрат, метан, центры кристаллизации, интенсификация, эффект самоконсервации, транспортирование

\section{ABOUT AUTHOR}

Sai Kateryna, Candidate of Technical Sciences, Associate Professor, Dnipro University of Technology, Associate Professor of the Mining Engineering and Education Department, 19 Yavornytskoho Ave., Dnipro, Ukraine, 49005, E-mail: kateryna.sai@gmail.com 